\title{
Effect of Bio-Fertilizers on Growth, Yield and Yield Attributing Characters of Brinjal
}

\author{
Gargi Gautami Padhiary ${ }^{1 *}$ and A. K. Dubey ${ }^{2}$ \\ ${ }^{1}$ Department of Vegetable Science, Odisha University of Agriculture and Technology Siripur, \\ Bhubaneswar, Odisha,751003, India \\ ${ }^{2}$ Department of Vegetable Science, Chandra Shekhar Azad University of Agriculture and \\ Technology, Kanpur, Uttar Pradesh, India \\ *Corresponding author
}

\section{A B S T R A C T}

\section{Keywords}

Brinjal, Biofertilizer, Azotobacter, Azospirillum, PSB, VAM

\section{Article Info}

Accepted: 12 February 2020 Available Online: 10 March 2020
A field study was conducted during the Kharif season of 2017-18 at Department of Vegetable Science, Kalyanpur, Chandra Shekhar Azad University of Agriculture and Technology, Kanpur to study about the effect of bio-fertilizers on growth, yield and yield attributing characters of Brinjal (Solanum melongena L.) cv. Azad B-3. The experiment was laid out in a randomized block design with 10 treatments replicated thrice. Four different bio-fertilizers viz., Azospirillum, Azotobacter, PSB (Phosphorous solubilizing bacteria) and VAM (Vesicular Arbuscular Mycorrhiza) were used alone and in different combinations with chemical fertilizers. All the bio-fertilizers are applied as seedling root dip method in which $200 \mathrm{~g}$ of each bio-fertilizers are dissolved in 3 liters of water in different containers. The roots of brinjal seedlings are dipped in it for 10 minutes immediately after transplanting and then transplanted into main field after keeping in shade for 5-10 minutes. Among all the treatments, it is noticed that the growth, yield and yield attributing parameters like plant height, number of primary branches, number of secondary branches, fruit length, fruit width, total number of fruits/ plot and fruit yield were found maximum with the application of Azospirillum + PSB $+75 \% \mathrm{~N}+$ Full P \& K and the minimum being recorded in control $\mathrm{T}_{1}$ in which no bio-fertilizers and chemical fertilizers were used. So based on the results it could be concluded that the application of Azospirillum and PSB in combination with $75 \% \mathrm{~N}$ and full N \& K favourably influenced the growth, yield and yield attributing characters in brinjal cv. Azad B-3

\section{Introduction}

Brinjal or eggplant (Solanum melongena L.) is a popular vegetable of solanaceous family widely grown in India and it is economically important due to its high nutritional and medicinal values. Bio-fertilizers are the preparations containing micro-organisms with capability of mobilizing nutritive elements from non-usable form to usable form through biological process. Bio-fertilizers improve the quantitative and qualitative features of many plants (Yosefi et al., 2011). Bio-fertilizers used in conjunction with chemical fertilizers 
improve crop productivity and nutrient use efficiency. In brinjal, generally Azotobacter, Azospirillum, Phosphate Solubilizing Bacteria (PSB) and VAM (Vesicular Arbuscular Mycorrhiza) are used.

Azotobacter are a group of aerobic, free-living soil microbes which play an important role in the nitrogen cycle in nature binding atmospheric nitrogen which is inaccessible to plants and releasing it in the form of ammonium ions into the soil (Nitrogen fixation). They can fix nitrogen equivalent to $30-40 \mathrm{~kg} \mathrm{~N} / \mathrm{ha}$. It also produces hormones like Indole Acetic Acid (IAA) and $\mathrm{GA}_{3}$, Vitamins like biotin and folic acid and supported by judicious use of organic matter, ensure good seed germination and increasing productivity.

Azospirillum is an eco-friendly liquid biological fertilizer formulation containing bacteria Azospirillum which contain large amount of lipid granules which enters the cortical cells of the root and fix up atmospheric nitrogen and also produces biologically active substances like vitamins, nicotinic acid, Indole Acetic Acid (IAA), Gibberllins, etc and better helps in retention of flowers and enhances plant growth. It fixes nitrogen equivalent to $40-50 \mathrm{~kg} / \mathrm{ha}$. It increases root biomass in the inoculated plant thereby helps in greater absorption of native nutrients in soil resulting in higher yield.

The phosphate solubilizing bacteria (PSB) may convert insoluble form of phosphate to soluble form by producing organic acids. About 15-25\% of insoluble phosphate can be solubilized saving chemical fertilizers significantly.

The endomycorrhizae otherwise known as Vesicular Arbuscular Mycorrhizae (VAM) is formed by the symbiotic association between certain phycomycetous fungi and angiosperm roots. It is found associating symbiotically with root of the plants and helps in greater absorption of phosphorous, water and other important macro and essential micro elements and making them available to the plants in an easily usable organic form. Besides they are also reported to impart resistance to plants against drought and soil borne fungal pathogens and nematodes.

Bio-fertilizers being cheap input, provide highly economic assurance, eco-friendly environment, sustain soil health and plant growth by adding organic contents as well as supplementing $25-40 \%$ of chemical fertilizers $\mathrm{N}$ and $\mathrm{P}$ requirement in terms of urea and DAP.It is becoming difficult to meet the nutrient need of farming through chemical fertilizers alone and due to its higher costs the concept of Integrated Plant Nutrient Supply System (IPNS) is gaining ground. Therefore, this present investigation was carried out to study about the effect of different biofertilizers on growth, yield and yield attributing characters of brinjal cv. Azad B-3.

\section{Materials and Methods}

The experiment was carried out in a Randomized Block Design(RBD) during kharif season of 2017-18 at Vegetable Research Farm, Department of Vegetable Science, Kalyanpur, Chandra Shekhar Azad University of Agriculture and Technology, Kanpur. The variety taken was Azad B-3 which is long fruited and shining purple in colour. Prior to the experiment, the mechanical and chemical analysis of the soil of the experimental field was done. 10 treatments were taken which were replicated thrice. The treatments were $\mathrm{T}_{1}($ Control $), \mathrm{T}_{2}(\mathrm{PSB}+$ Azotobacter $+75 \% \mathrm{P}+$ Full $\mathrm{N} \& \mathrm{~K}), \mathrm{T}_{3}$ (Azotobacter+ Azospirillum + $75 \% \mathrm{~N}+$ Full $\mathrm{P} \& \mathrm{~K}), \mathrm{T}_{4}(\mathrm{PSB}+\mathrm{VAM}+75 \%$ $\mathrm{P}+$ Full $\mathrm{N} \& \mathrm{~K}), \mathrm{T}_{5}$ (Azospirillum $+\mathrm{PSB}+75 \%$ $\mathrm{N}+$ Full $\mathrm{P} \quad \& \mathrm{~K}$ ), $\mathrm{T}_{6}$ (Azospirillum $+\mathrm{RDF}$ $\mathrm{NPK}), \mathrm{T}_{7}($ Azotobacter $+\mathrm{RDF} \mathrm{NPK}), \mathrm{T}_{8}(\mathrm{PSB}$ 
+ RDF NPK), $\mathrm{T}_{9}(\mathrm{VAM}+\mathrm{RDF}$ NPK), $\mathrm{T}_{10}$ (RDF NPK). Bio-fertilizers were applied as seedling root dip method. $200 \mathrm{~g}$ each of biofertilizers dissolved in 3 liters of water in different containers. Immediately after uprooting, the roots of disease free healthy brinjal seedlings of 45 days old were dipped in this solution separately for 10 minutes and kept in shade for drying for 5-10 minutes and then transplanted to main field. Five plants from each treatment were selected at random and tagged for recording the observations. The analysis of variance and interpretation of data were done as per procedures given by Chandel(1999).

\section{Results and Discussion}

\section{Effect of bio-fertilizers on plant height}

Statistical analysis revealed that treatment $\mathrm{T}_{5}$ (Azospirillum + PSB + 75\% N + Full P \& K) recorded maximum plant height $(96.23 \mathrm{~cm})$ which is significantly higher over the rest of treatments. The treatment $T_{5}$ has maximum height followed by $T_{4}$ and $T_{2}$ over control $\mathrm{T}_{1}$ which showed the minimum plant height $(79.15 \mathrm{~cm})$.

\section{Effect of bio-fertilizers on number of primary branches}

Statistical analysis showed that treatment $\mathrm{T}_{5}$ (Azospirillum + PSB + 75\% N + Full P \& K) recorded more number of primary branches (6.32) which is significantly higher over the rest of treatments and it is followed by $\mathrm{T}_{4}$ and $\mathrm{T}_{9}$ over control $\mathrm{T}_{1}$ which showed the lowest number of primary branches (3.95).

\section{Effect of bio-fertilizers on number of secondary branches}

Statistical analysis indicated that treatment $\mathrm{T}_{5}$ (Azospirillum + PSB + 75\% N + Full P\& K) recorded maximum number of secondary branches (11.27) which is followed by $\mathrm{T}_{4}$ and $\mathrm{T}_{9}$ and the minimum number being recorded in $\mathrm{T}_{1}$ (Control) which is 7.15.

\section{Effect of bio-fertilizers on fruit length(cm)}

Statistical analysis revealed that treatment $\mathrm{T}_{5}$ (Azospirillum + PSB + 75\% N + Full P\& K) recorded maximum fruit length $(13.89 \mathrm{~cm})$ which is higher over rest of the treatments and is followed by $T_{4}$ and $T_{2}$ and the lowest fruit length found in control $\left(\mathrm{T}_{1}\right)$ i.e, $7.25 \mathrm{~cm}$.

\section{Effect of bio-fertilizers on fruit width(cm)}

Statistical analysis showed that treatment $\mathrm{T}_{5}$ (Azospirillum + PSB + 75\% N + Full P\& K) has increased fruit width $(8.42 \mathrm{~cm})$ which is significantly higher over rest of the treatments. $\mathrm{T}_{5}$ has maximum fruit width followed by $\mathrm{T}_{4}$ and $\mathrm{T}_{9}$ over the control $\mathrm{T}_{1}$ which showed lowest fruit width $(6.65 \mathrm{~cm})$.

\section{Effect of bio-fertilizers on number of fruits per plot}

Statistical analysis revealed that treatment $\mathrm{T}_{5}$ (Azospirillum + PSB + 75\% N + Full P \& K) has increased total number of fruits per plot (724.66) which is significantly higher over rest of the treatments. $\mathrm{T}_{5}$ has maximum number of fruits per plot followed by $\mathrm{T}_{4}$ and $\mathrm{T}_{2}$ over the control $\mathrm{T}_{1}$ which showed minimum number of fruits per plot (580.00).

\section{Effect of bio-fertilizers fruit yield (q/ha)}

Statistical analysis revealed that treatment $\mathrm{T}_{5}$ (Azospirillum + PSB + 75\% N + Full P\& K) possessed the highest fruit yield (448.65 q/ha) which is significantly higher over the rest of the treatments. It is followed by $\mathrm{T}_{4}$ and $\mathrm{T}_{2}$ over the control. The lowest yield recorded in the treatment $\mathrm{T}_{1}(237.44 \mathrm{q} / \mathrm{ha})$. 
Table.1 Effect of bio-fertilizers on growth, yield and yield attributing characters of brinjal

\begin{tabular}{|c|c|c|c|c|c|c|c|}
\hline Treatment & $\begin{array}{c}\text { Plant } \\
\text { height(cm) }\end{array}$ & $\begin{array}{c}\text { No. of } \\
\text { primary } \\
\text { branches }\end{array}$ & $\begin{array}{c}\text { No. of } \\
\text { secondary } \\
\text { branches }\end{array}$ & $\begin{array}{c}\text { Fruit } \\
\text { length(cm) }\end{array}$ & $\begin{array}{c}\text { Fruit } \\
\text { width(cm) }\end{array}$ & $\begin{array}{c}\text { Total no. } \\
\text { of fruits } \\
\text { per plot }\end{array}$ & $\begin{array}{c}\text { Yield } \\
\text { (q/ha) }\end{array}$ \\
\hline $\mathbf{T}_{\mathbf{1}}$ & 79.15 & 3.95 & 7.15 & 7.25 & 6.65 & 580.00 & 237.44 \\
\hline $\mathbf{T}_{\mathbf{2}}$ & 92.30 & 5.48 & 9.42 & 12.24 & 8.08 & 698.00 & 404.35 \\
\hline $\mathbf{T}_{\mathbf{3}}$ & 86.66 & 4.50 & 9.21 & 9.42 & 7.50 & 682.33 & 332.48 \\
\hline $\mathbf{T}_{\mathbf{4}}$ & 93.41 & 5.88 & 11.21 & 12.87 & 8.41 & 705.33 & 413.26 \\
\hline $\mathbf{T}_{\mathbf{5}}$ & 96.23 & 6.32 & 11.27 & 13.89 & 8.42 & 724.66 & 448.65 \\
\hline $\mathbf{T}_{\mathbf{6}}$ & 86.30 & 4.56 & 10.43 & 10.91 & 8.02 & 676.00 & 378.10 \\
\hline $\mathbf{T}_{\mathbf{7}}$ & 90.11 & 5.07 & 10.12 & 10.82 & 7.94 & 695.33 & 336.81 \\
\hline $\mathbf{T}_{\mathbf{8}}$ & 90.52 & 4.35 & 9.90 & 10.47 & 7.75 & 672.33 & 360.20 \\
\hline $\mathbf{T}_{\mathbf{9}}$ & 92.19 & 5.63 & 10.93 & 11.94 & 8.27 & 636.66 & 393.00 \\
\hline $\mathbf{T}_{\mathbf{1 0}}$ & 83.25 & 4.24 & 8.25 & 9.04 & 8.00 & 625.66 & 291.12 \\
\hline $\mathbf{C . D .}$ & 5.16 & 1.21 & 1.82 & 1.45 & 0.60 & 43.20 & 50.77 \\
\hline
\end{tabular}

Effect of bio-fertilizers on plant growth and its characteristics

The various bio-fertilizers affected plant height, number of primary branches and number of secondary branches significantly. Maximum plant height, number of primary branches and secondary branches were recorded in $\mathrm{T}_{5}$ (Azospirillum $+\mathrm{PSB}+75 \% \mathrm{~N}$ + Full $\mathrm{P} \& \mathrm{~K})$ and the minimum being recorded in $\mathrm{T}_{1}$ (control).

Significant increase in plant height, number of primary branches and number of secondary branches are due to increased uptake of nutrients in the plant leading to enhanced chlorophyll content and carbohydrate synthesis and increased activity of hormones produced by Azospirillum and phosphate solubilizing bacteria (PSB). The PSB seedling root treatment increased phosphate availability in soil which in turn helped better proliferation of root growth and uptake of other nutrients to the greater extent so that there is enlargement in cell size and cell division which might have helped in increasing plant height, number of primary and secondary branches.
Effect of bio-fertilizers on yield and yield attributing characters

Application of different bio-fertilizers influenced significantly fruit yield and its components. Significant increase in the fruit length, fruit width, number of fruits and fruit yield per plot are found maximum in $\mathrm{T}_{5}$ (Azospirillum + PSB $+75 \% \mathrm{~N}+$ Full $\mathrm{P} \& \mathrm{~K}$ ) and the minimum found in $\mathrm{T}_{1}$ (control).

Increase in fruit yield and its parameters may be due to increase in number of branches which produced more leaves and this worked as an efficient photosynthesis structure and produced high amount of carbohydrate in the plant. More number of branches produced more number of flowers which resulted higher fruits per plant and increased fruit yield and their attributes.

From the result of present investigation, it is concluded that in order to obtain higher yield in brinjal, it is better to go for application of Azospirillum + PSB $+75 \% \mathrm{~N}+$ Full P \&K ( in which both the bio-fertilizers are applied as root dipping @ $200 \mathrm{~g}$ dissolved in 3 liters of water ) under the agro-climatic conditions of Central Uttar Pradesh. 


\section{References}

Amirthalingam, S.and Balakrishnan, N.(1988) Studies on the effect of Azospirillum, nitrogen and NAA on growth and yield of chilli. South Indian Hort.; 36:218.

Dhumal, K.N. (1992) Effect of Azotobacter on germination, growth and yield of some vegetables. J. Maharashtra Agric. Univ. 17 (3): 500.

Gaikwad.R.M.andWani, P.V. (2001) Response of Brinjal (cv.Krishna) to Phosphate Solubilizing Biofertilizers. J. Maharashtra Agric. Univ., 26 (1): 029032.

Kumaran, S. S.,Natarajan, S. andThamburaj, (1998) S. Effect of organic and inorganic fertilizers on growth, yield and quality of tomato. South Indian Mori.;46(3/6):203- 205.

Manjusha, S. (1996) Response of culture with graded doses of nitrogen on growth, yield and quality of Brinjal and Tomato, M.Sc. (Agri.) Thesis (Unpub), Dr. P.D.K.V. Akola, (India).

Naidu, A. K., Kushwah, S. S. and Dwivedi, Y.C., (2002) Influence of organic manures, chemical and bio-fertilizer on growth, yield and economics of brinjal. South Indian Horticulture; 50(4/6): 370376.

Nathakumar, S. and Veeraragavatham, D.,
(2001) Effect of integrated nutrient management on yield and quality attributes of brinjal (Solanummelomgena) cv. Palur 1. South Indian Horticulture; 49: SI, 195198.

Pal, M.L. (1996) Efffect of Azotobacter, Azospirillum alone and in combination with reduced doses of $\mathrm{N}$ on growth and yield of Brinjal. Thesis submitted to Dr. PanjabraoDeshmukh Agriculture University, Akola (India).

Prabhu, M., Veeraraghavathatham, D., Srinivasam, K. (2003).Effect of nitrogen and phosphorous on growth and yield of brinjal hybrid COBH-1. South Indian Hort.; 51(1- 6):152-156.

Verma, O.P. and Shende, S.T. (1993) Azotobacter a biofertilizer for vegetable crops: Biofert. Newsletter.1(2):6-10.

Wange, S.S. and Kale, R.H. (2004) Effect of biofertilizers under graded nitrogen levels on Brinjal crop; J. Soils and Crops. 14 (1): 9-11.

Yosefi, K., Galavi, M., Ramrodi, M., and Mousavi, S.R. (2011) Effect of biophosphate and chemical phosphorus fertilizer accompanied with micronutrient foliar application on growth, yield and yield components of maize (Single Cross 704.) Australian J. of Crop Science, 5: 175 - 180.

\section{How to cite this article:}

Gargi Gautami Padhiary and Dubey. A. K. 2020. Effect of Bio-Fertilizers on Growth, Yield and Yield Attributing Characters of Brinjal. Int.J.Curr.Microbiol.App.Sci. 9(03): 1643-1647. doi: https://doi.org/10.20546/ijcmas.2020.903.192 